\title{
The place of metaphysics in the science-religion debate
}

Author:

Daniël P. Veldsman'10

\section{Affiliation:}

${ }^{1}$ Department of Dogmatics and Christian Ethics, Faculty of Theology, University of Pretoria, South Africa

Research Project Registration: Project Leader: D.P. Veldsman Project Number: 01224719

\section{Description:}

This research is part of the research project, 'Religious Experience from an evolutionary perspective', directed by Prof. Dr Danie Veldsman, Department Dogmatics and Christian Ethics, Faculty of Theology, University of Pretoria.

\section{Corresponding author:} Daniël Veldsman, danie.veldsman@up.ac.za

Dates:

Received: 15 May 2017 Accepted: 12 Sept. 2017

Published: 15 Nov. 2017

How to cite this article: Veldsman, D.P., 2017, 'The place of metaphysics in the science-religion debate', HTS Teologiese Studies/ Theological Studies 73(3), a4655. https://doi. org/10.4102/hts.v73i3.4655

\section{Copyright:}

C) 2017. The Authors. Licensee: AOSIS. This work is licensed under the Creative Commons Attribution License.

\section{Read online:}

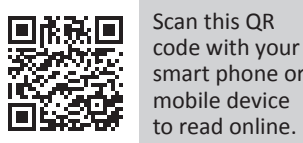

Metaphysics has no place in the science-religion discourses (or dialogues) if understood as an a priori universal content of the nature and causes of all things. From an overview of the positive and negative dimensions and challenges of the contemporary science-religion discourses within each conversation partner itself and between the two, it is argued that metaphysical reflection represents a contextual-linguistic event that 'takes place' only after the contextual giveness is taken up within a very concrete historical-linguistic frame of reference for sense making. In a metaphoric sense, it is conclusively compared with the movements of atoms of which we can only state afterwards where the atoms have been. In this sense, McGrath's remark that '(m)etaphysics is not the precondition of any engagement with the world, but its inferred consequence' is supported. The 'was' of metaphysical thinking represents the emergent product of the concrete and specific lifeworlds in which they have 'taken place', that is, 'eventuated'. The 'was' of metaphysical reflection is the most powerful (a posteriori) event of credofication (i.e. understanding life in terms of convictions of faith) for human beings in living, making sense of and participating empathically in the question 'why there is something rather than nothing?'.

\section{Introduction}

For conscious ${ }^{1}$ embodied human beings, metaphysics is a given. It is a constitutive and an unavoidable given. It can most probably be best described - in short - as reflection on the nature and basic causes of all things. ${ }^{2}$ However, even in this short and apparent simple description lurks a deep ideologically tainted misconception of metaphysics that resulted from an influential historical twist to the use of the word 'metaphysics'. The word comes from the Greek $\mu \varepsilon \tau$ ó (metá, 'beyond', 'upon' or 'after') and pvбıкá (physiká, 'physics'). Although the word is usually associated with the works of Aristotle (see Gill 2005 for a good overview), he did not use the word himself. He himself called the chapters that came after his reflection on physics 'First Philosophy'. However, the editor of Aristotle's works, Andronicus of Rhodes, is thought to have placed the books on first philosophy right after another work, Physics. He subsequently called them 'the books that come after the (books on) physics'. And now the historical twist. The Latin commentators misunderstood (misread?) meta-physics not as books that come after, but as the science of what is beyond the physical. It is their 'misunderstanding' that opened up in its historical wake all kinds of ideological 'justifications' for their standpoints such as metaphysics as the science of the world beyond nature, that is, the science of the immaterial or viewpoints that equates the metaphysical to the non-physical. For many scholars who are highly critical of 'metaphysical reflection', this is unfortunately still the case.

In my opinion, the best description for prompting reflection on metaphysics that remains until this day is that of the German philosopher Gottfried Wilhelm Leibniz (1646-1716): ‘Why is there something rather than nothing?'. Spontaneously, the question that subsequently follows for conscious embodied human beings reads: What then is the nature of the 'somethings' (i.e. 'being as being' or beingness as all of reality of which we seek knowledge and the causes thereof)?

1.I speak on behalf of conscious embodied human beings on the place of metaphysics. I can only acknowledge the possibility of 'a place of metaphysics' within the realm of non-human conscious being. For commentary on the non-human conscious being, see Southgate's (2016:373) discussion of work being done in the United Kingdom.

2.For interest sake, I would like to add three remarks. Maudlin (2003) describes metaphysics in the Oxford Handbook of Metaphysics as follows: Metaphysics is the theory of being, that is, the most generic account of what there is. As such, it must be informed by empirical science, since we can only discover the nature of the material world through our experience of it. The most general and fundamental science, since we can only discover the nature of the material world through our experience of it. The most general and fundamental with) metaphysics as a philosophical inquiry (p. 461). In his short summary of metaphysics, Van der Meer (2003:561) writes, 'The term metaphysics refers to the study of things that are removed from sense perception. Modern metaphysics studies the kind of things that exist and the way they exist'. Van der Meer (2003:563) talks about 'renewed interest in metaphysics' which - according to him - 'has revealed that it often mediates between science and religion'. How that is the case, he does not elaborate on. McGrath (2004:235) is more cautious to offer a firm definition of the term because there is - according to him - a widespread lack of agreement on what the term denotes. He does, however, in spite of his cautionary remark, give a description, namely as a study of 'ultimate reality', including such questions as why the world exists and what place humanity has within it. 
For conscious human beings, metaphysics has a givenness that has RSVP (French phrase 'répondez, s'il vous plaît' which is translated in English: Please reply) 'written all over it', that is, it invites reflection and sense making. As human beings according to Heidegger (2001:36ff.) - we are conscious of our 'Verfallenheit und Geworfenheit' that belongs to the 'Wahrheit' of our 'Existenz'. We explore and discover in our reflections and with curiosity the RSVP character of our being. Heidegger calls it the 'Rätselhaftigkeit des Daseins: der Frage nach dem Woher und Wohin des Daseins'. Put differently in an integrated formulation: From our conscious awareness of 'being thrown' into a world of existence, we are invited to make sense of the world (that we are thrown into) and of our being in the world. Making sense of the world and of our being in the world is undertaken from within a concrete and very specific 'Gestimmtheit' ${ }^{3}$ and from many diverse contexts and angles. It finds expression in extremely diverse manners and takes on various expressive forms.

If this can be accepted and taken as a vantage point for my reflection on the 'place' of metaphysics, I have to start from 'my place', that is, my historical-contextual situatedness ('embeddedness') as a 21st century religious (with Christian orientation) South African white male from Pretoria, Gauteng. This is my 'placedness'. ${ }^{4}$

Two pre-remarks must suffice before I embark from where I am on the question of the place of metaphysics. The one is a statement, the other a short humoristic story.

\section{Firstly: The statement}

I take it that we will all agree from a hermeneutical perspective with the famous 19th century words of Molly Bawn from the book (1878) with the same title, written by the Irish novelist Margaret Wolfe Hungerford (Wikipedia 2017a).

\section{Beauty is in the eye of the beholder}

Indeed, reflection on the 'art of understanding' (hermeneutics) has established this insight of the constitutive and deep and wide ranging role of the interpreter beyond question. With regard to the 'interpretation of metaphysics', it is no different.

\section{Secondly: The story}

Many years ago, a spelling contest was conducted between an American, Englishman and Boer. They had to complete the sentence and spell the word that they have completed the sentence with. The sentence was: 'Old MacDonald had a ....?' The American answered first: 'Ranch' and spelt it: 'r-a-n-c-h'. Not correct. The Englishman said: 'Estate' and spelt it 'e-s-t-

3.'Gestimmtheit' carries the strong emotive tone of mood ('Gemut'), but then as psycho-existential attitude towards reality in the sense-making processes that colours and determines those very processes. I call it simply the affective-cognitive dimension of human beings (cf. Veldsman 2014)

4.There is no such word as 'placedness' in the English language. I playfully coined the term in reference to an insightful paragraph by the Oxford theologian Brooke (2006:302) on 'The Place of Places' in his contribution on 'The history of science and religion' in The Oxford Handbook of Science and Religion. Regarding the significance of 'place', he makes the following observation: 'The critical point is that whether a porticular piece of science is perceived as friend or enemy may crucially depend on
partion particular piece of science is percei
local events and circumstances'. a-t-e'. Also not correct. The Boer said: 'farm', but then unfortunately, the following spelling ensued: 'e-i-e-i-o'.

The simple story simply emphasises in a humoristic manner the contextual-linguistic nature of 'making sense'. With regard to the question of metaphysics, it is no different.

If I put the two together, the following is implicated for our question: In the dense and robust contemporary religionscience discourses, we find that the question on the place of metaphysics is answered by the 'Beholders' from their 'places' and their specific 'Gestimmtheit'. I am firstly going to make a few broad comments on our respective 'places' (the conversation partners) from which reflection on metaphysics is springing influentially forth (being@home) ${ }^{5}$ and what is currently 'reflectively brewing'; and finally, I will give an indication where I find myself on the question of the place of metaphysics.

\section{Places for being@home}

Within the contemporary science-religion discourses, many dimensions have come into play not only on each respective side of the conversation partners ${ }^{6}$ but also within the configuration of the relationship itself. The following brief remarks on each conversation partner and the relationship has to suffice. It will be structured according to contemporary developments: negative, positive and direction of the main discourses.

Within the natural sciences, we have - as negative thrust - the ongoing and deepening of the collapse of the reductionistic programme (Clayton 2005:344ff.; Gillett 2006:801ff.; Scott 2016). According to the American philosopher Philip Clayton, the physical sciences have encountered what appeared to be permanent limits to the dream of a single explanatory system from which all the world's phenomena could be derived.? And the winds that brought about the collapse not only came from many sides. It took on the strength of tornados! Tornados - to name but a few - in the form of relativity theory (issue: speed of light as the absolute limit for velocity and thus as the temporal limit for communication and causation); the uncertainty principle (issue: mathematical limits on knowability of both the location and momentum of a subatomic particle); quantum mechanical interdeterminacy (issue: not only an temporary epistemic problem, but reflected an inherent interdeterminacy of the physical world itself); chaos theory (issue: future states of complex system easily become incomputable because of their sensitive dependence on initial conditions); and lastly - although there

5.The phrase "being@home' is playfully formulated to capture and emphasise the 'contextuality' of all sense-making activities.

6.The most important conversation partners I have in mind here are philosophy of science, the natural sciences and religions.

7.The historical background to the establishment of the most influential interpretative framework within the natural sciences goes back to the philosophical movement called the 'Vienna Circle' (1924-1936). All that counted was experience, and then called the 'Vienna Circle' (1924-1936). All that counted was experience, and then specifically empirical experience found in observation. Everything one said about that which is, had to be 'spelt' in direct relation to what we experience. Statements that did not reflect or relate directly to the real world were senseless. This implied an outright rejection of metaphysics. See Van Huyssteen (1986:15ff.) for an in-depth analysis of the Vienna Circle. 
are many more to be mentioned - mathematics (issue: not complete!). Apart from the conditions from the inside, other less favourable weather conditions developed from the 'outside' such as the increased emphasis on holistic factors in the philosophy of science, the waning influence of analytic philosophy, the collapse of 'foundationalism' in epistemology and new data in support of emergence in the natural world. ${ }^{8}$ These 'outside' developments, however, prompted very positive reflective directions within the natural sciences such as an increasing awareness of the influence of metaphysical presuppositions on the actual practice of science (Clayton 2005:344; Gillett 2006:802; cf. McGrath 2004:239; Scott 2015; 2016). ${ }^{9}$ This we find in the manner that the sciences reflect on the nature of reality, ontology, being - and in so doing, presents us with answers that are based on physical insights but with a 'healthy admixture of metaphysics' (Du Toit 2013:6). He subsequently lists a few examples, namely: why natural laws are what they are; chance and multiplicity; space and time, the quantum world; parallel universes; origin of matter; nature of autopoietic systems and of human consciousness; emergence and the nature of creativity (cf. Du Toit 2013:6). In an earlier publication, McGrath (2004:239) makes the same point: 'Metaphysical assumptions are actually implicit within the ideologies of those who oppose the notion'. The South African mathematician Ellis (2006:761) adamantly states in his essay on Physics, Complexity and Religion that there are major metaphysical issues underlying the existence of nature. He then convincingly states:

One can ignore these ultimate issues if one wants to, taking the nature of the universe and the laws of physics for granted, and not needing explanation, but then precisely because one has done so, one is in no position to declaim on issues of higher meaning and purpose, one has simply chosen to exclude them from consideration a priori.

A more difficult issue to address is insightfully discussed by Ormerod (2013). He takes on the 'metaphysical muddle' of the influential book A Universe from Nothing (2012) by the physicist Lawrence Kraus. He accuses Kraus of what he calls the 'blurring of the distinction between physics and metaphysics' (Ormerod 2013:961).

Within the realm of theological/religious reflection, the weather conditions are very much the same with a turbulent wide spectrum of infernos, tornados and thunderstorms! Strong negative thrusts from the outside as well as the inside of the religious realm are determining the reflections as well as the 'Gestimmtheit' of the reflections. From the 'outside', the

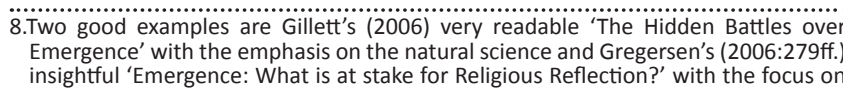
insightful 'Emergence:
theological reflection.

9.Clayton (2005) emphatically states regarding the wide-ranging changes that are taking place within the context of the physical sciences: The collection of changes, including in particular the collapse of foundationalism in epistemology, has produced a new climate now widely referred to (albeit misleadingly) as postmodernism. Taken together, these changes amount to an invitation for theologians, and metaphysicians in general, to take on anew the task of systematizing the various segments of human knowledge and belief (p. 344).

The British-American philosopher Gillett (2006:802) insightfully argues that reductionism in the natural sciences is 'actually metaphysical in nature, and largely impervious to empirical data'. He talks about the 'hidden metaphysical engine' of ontological reductionism. words of the Canadian philosopher Taylor (2007) most probably capture the thrust in the Western context the best in talking about a cultural shift that - according to him - is characterised by:

... a move from a society where belief in God is unchallenged and indeed, unproblematic, to one in which it is understood to be one option among others, and frequently not the easiest to embrace ... Belief in God is no longer axiomatic. There are alternatives ... (p. 3)

For the French philosopher Badiou (2006), there are no alternatives, ${ }^{10}$ when he earlier remarks on the cultural shift in a more radical manner:

I take the formula 'God is dead' literally. It has happened ... God is finished. And religion is finished too ... (p. 23)

The strongest and probably the most influential contemporary attack against religion in the West that fuels the 'God is dead' position surely comes from the New Atheists. ${ }^{11}$ The reason why they are extremely important in this context is that they make the natural sciences the focus of many (most?) of their arguments that are directed towards religion (Du Toit 2013:1ff.; cf. McGrath 2011:33ff.; Ormerod 2013:187ff.; Scott 2016:1ff.; Southgate 2016:377). For them, the sciences represent the sole basis of reliable truth! And with that comes the rejection of religious belief as evidence-free superstition. McGrath (2011:35) refers to two of the well-known New Atheists, namely Dawkins and Dennett, that they both believe that the natural sciences exclude metaphysical commitments, especially of a religious nature, holding that these are ultimately spurious. However, McGrath (2011:35) argues that Dawkins is a 'master of smuggling metaphysics into science, rewriting the neutral and inconclusive scientific narrative so that it leads to a rigorous atheist conclusion'. The point that McGrath clearly makes - and subsequently illustrates - is that Dawkins imposes an atheistic metanarrative on a scientific description of things. In other contexts (especially more strongly Evangelical and Charismaticorientated contexts that we find in Africa and Asia, and also certain parts of America - to name only but a few), the negativity comes from the religious side and is with fervour directed towards the (natural) sciences! ${ }^{12}$

10.A flood of literature has been published over the last two decades that is in support of the 'alternatives'. To name but a few very critical examples of which the titles are already telling: Why People Believe Weird Things: Pseudoscience, Superstition, and Other Confusions of Our Time (Shermer 1997); The End of Faith: Religion, Terror, Other Confusions of Our Time (Shermer 1997); The End of Faith: Religion, Terror, and the Future of Reason (Harris 2004); Atheist Manifesto: The Case Agains Christianity, Judaism, and Islam (Onfray 2005); The God Delusion (Dawkins 2006); Letter to a Christian Nation (Harris 2006); Breaking the Spell: Religion as a Natura Phenomenon (Dennett 2006); God: The Failed Hypothesis-How Science Show That God Does Not Exist (Stenger 2007); God Is not Great: How Religion Poison Everything (Hitchens 2007); Why Are You Atheists So Angry? 99 Things That Piss Off the Godless (Christina 2012); Fighting God: An Atheist Manifesto for a Religious World (Silverman 2015); Skeptic: Viewing the World with a Rational Eye (Shermer 2016); Unapologetic: Why Philosophy of Religion Must End (Loftus 2016), and God: The Most Unpleasant Character in All Fiction (Dan Barker 2016)

11.Southgate (2016) remarks: The significance of the new atheists for the wider science-religion debate is partly rhetorical - it is important to notice how they tend to use science to claim an intellectual authority which is then deployed to give weight to a range of other types of critique of (especially the Abrahamic) religions (p. 377)

12.Only a few references must suffice. The range of the literature is very wide from sophisticated philosophical defences such as the impressive work No God, no science (2013) of the Roman Catholic theologian Michael Hanby from the Pontifical John Paul II Institute, Catholic University of America, to the much more popular theological works of the British theologian Allister McGrath of Oxford University theological works of the British theologian Allister McGrath of Oxford University -
with a vast number of books. In the South African context, especially the works of 
Apart from the thrusts that I have characterised as coming from the 'outside', there are simultaneously negative thrusts (or perhaps better understood as challenges!) coming from - as it were - the inside. There are more, but I see the following two negative thrusts (or challenges) as the most compelling, namely the issue of divine action and the stance towards metaphysics, that is, a fundamental outright rejection of metaphysics by some theologians in Christian theology. Two remarks on each much suffice. Firstly, within contemporary theological discourses on divine agency, it has become clear that most of the viewpoints on divine agency were based upon those gaps in human knowledge of the relevant natural processes that were prevalent in that specific period. As knowledge on these very laws that govern these processes increased, it correlated with an increase in direct conflict with these influential traditional theological standpoints. Philip Clayton (2005:345) calls it the 'single greatest challenge to theology'. Secondly, to briefly mention but two theologians who have opposed 'metaphysics'. The American theologian Kaufman (1978:325ff) has already in the late seventies of the previous century argued that there is an 'inescapable rivalry between metaphysics and theology'. To address the rivalry, metaphysics had to be eliminated. Within the circle of the 'Radical Orthodoxy', ${ }^{13}$ we find a much more recent rejection of metaphysics. In the words of the Anglican theologian John Millbank (1952-) from the University of Nottingham who wrote that metaphysics is 'tainted on account of its autonomous pretensions or antitheistic presuppositions' (referred to by McGrath 2004:237). For Millbank, metaphysics is to be rejected on account of its pretensions to theological autonomy, that is, its efforts in seeking a graspable immanent security (see McGrath 2004:240). It - according to Millbank - should therefore be eliminated from theological reflection for two good reasons: firstly, it is theologically unnecessary, and secondly, it is degrading. The first reason of being unnecessary comes from the conviction that the Christian revelation of God needs no philosophical support. The second reason of being degrading comes from the conviction that metaphysics is intellectually contaminated by the presuppositions of a secular world (cf. McGrath 2004:240). McGrath (2004:240-241) rightly questions the argument of Millbank, calling it a 'puzzling argument', because it seems to rest on the 'assumption that metaphysics is an a priori discipline which lays down in advance what can and cannot be said or thought ... about God'.

In my opinion, the strongest contemporary thrusts as direction of development lie in taking on reflection after the so-called end

\footnotetext{
(footnote 12 continues...)
}

Klaus Nürnberger, emeritus systematic theologian of the University of KwaZuluNatal, needs to be mentioned, namely Richard Dawkins' God Delusion: A repentan refutation (2010); Regaining sanity for the earth: Why science needs 'best faith' to be responsible, why faith needs 'best science' to be credible (2011); and Informed by science, involved by Christ: How science can update, enrich and empower the Christian faith (2013). In 2016, his two-volume book Faith in Christ: Invitation to Systematic Theology was published.

13. Radical Orthodoxy's beginnings in the United Kingdom are found in a series of books edited by John Milbank, Catherine Pickstock and Graham Ward. The name 'Radical Orthodoxy' emphasises the movement's attempt to return to or revive traditional doctrine. The movement reclaims the original early church idea that theology is the 'queen of the sciences'. This means that if the world is to be interpreted correctly, it must be viewed from the perspectives of theology. Radical Orthodoxy critiques secular sciences because their worldview is considered inherently atheistic and nihilistic, based on acts of ontological violence considered inherently
(cf. Wikipedia 2017b) of metaphysics (Nietzsche). The one is philosophicaltheological, whereas the other thrust stems from a proposal on human social evolution, that is, on evolutionary processes related to the emergence of humanity. Firstly, let us discuss the philosophical-theological approaches. At their core, we find a radical rejection of traditional 'onto-theological' viewpoints. ${ }^{14}$ The critical insights that stem from these very rejections - in my opinion - can be extremely helpful within the broader theology-science dialogues. For me, some of the most important critical features lie with issues such as actuality being replaced by possibility, the radical critique of - what is called-idolatrous representations, causality replaced by givenness, death of the mastery of objects as well as the death of the longing for objectivity. Secondly, one outstanding example - in my opinion - of how traditional dualistic approaches are radically revised within more holistic integrated science-theological approaches (i.e. on evolutionary processes related to the emergence of humanity) comes from the work of the American primatologist Agustin Fuentes ${ }^{15}$ (University of Notre Dame). We find in his so-called niche construction and religious evolution that he endeavours to understand the human propensity for religious behaviour from the core role of the evolutionary processes in the emergence of humanity.

The niche construction approach to religious evolution provides an alternative to the primarily functionalist and reductive approach (Fuentes 2015:1). This way of approaching the human niche, and human evolution, lays a groundwork for modelling the development of the structures (cognitive and behavioural) that can facilitate a more comprehensive, and less reductive, understanding of the human propensity for imagination, faith and ritual. His approach - and for me, this is the important contribution of Fuentes - suggests that a distinctively human imagination, and a uniquely human metaphysics, is a core part of being human and thus part of the explanation for human evolutionary success (Fuentes 2015:1).

With regard to the relationship, that is, between science and religion (theology), the contemporary thrusts are extremely diverse and different from context to context.

14.To give but one example of the current thrust. On 19-20 April 2017, the Institute of Philosophy of KU Leuven (Belgium) organised a symposium entitled 'Between Metaphysics, Aesthetics and Religion' in honour of the retirement of Prof. William Desmond. The theme of the symposium was the metaxological philosophy of William Desmond. 'Metaxology' is the key term of Desmond's philosophy, which is a way of doing philosophy in the 'between'. Central to this style of philosophising is a 'porosity' to an 'osordeterminacy' in terms of a surplus to (self)determinte being 'porosity' to an 'overdeterminacy', in terms of a surplus to (self) determinate being that resists 'univocal' or 'dialectical' (self)mediation, which in turn engenders 'perplexity' towards such a 'surd' to determination. The task of metaxological "philosophy is then to stay faithful to what exceeds univocalising thought by allowing reflection to hyperbolically (i.e. to 'be thrown beyond') transcend itself for a metaphysical account of being. Central to metaxological philosophy is then profound engagement with being (metaphysics), being good/beautiful (ethics and aesthetics) and absolute being (religion). Among the many thought-provoking features of metaxology, there are two that merit special mention here since they go against the grain of postmodern philosophy. On the one hand, metaxology cultivates a community in which there is an open dialectics between being, goodness, beauty and absolute being; on the other hand, metaxology does not shun a metaphysical account of that open dialectics, in which porosity between being receptive (porosity) and being active (thought) is of central importance. Needless to say, most of postmodern philosophy prefers to separate being, goodness, beauty and absolute being into their respective domains. This symposium is dedicated to clarifying testing and applying metaolo a h. This sy and religion (see https://hiw.kuleuven.be/eng/events/symposium-metaphysics).

15.Fuentes' recent books include Evolution of Human Behavior (2009); Race, Monogamy, and Other Lies They Told You: Busting Myths about Human Nature (2012); Conversations on Human Nature(s) (2015); and The Creative Spark: How Imagination Made Humans Exceptional (2017). 
Almost two decades ago, the South African theologian Wentzel van Huyssteen and the Danish theologian Gregersen (1998:1) wrote in their introduction to Theology and Science in a Pluralist World:

Gone are the days in which any attempt to relate theology and science to one another could still be possibly - and mistakenly seen as a rather esoteric, intellectualist exercise limited to a privilege few. 'Theology and science', as a very focused interdisciplinary venture is indeed alive and well today on both sides of the Atlantic, as theologians, as scientists, and philosophers are joining this complex cross-interdisciplinary conversation with its ever-new challenges and configurations. It seems that this ancient and enduring dialogue has managed to successfully transform itself, in our present Western culture, into a sustained and dynamic contemporary discourse with its own identity for our times. (Gregersen \& Van Huyssteen 1998:1)

The claim by these two authors of more than two decades ago that the 'dialogue has managed to successfully transform itself, in our present Western culture, into a sustained and dynamic contemporary discourse' is in 2017 only (scarcely!) justified within certain contexts. 'Glocally' it is surely not a defendable statement at all. Let me elaborate on and substantiate my critique from a series of articles published on religion-science dialogues around the world.

Zygon, the well-known America-based journal of religion and science, published a series of articles in 2015-2016 on the science-religion dialogues around the world (see Drees 2015a; 2015b). I have found these articles not only to be extremely insightful but also to confirm that the Van Huyssteen and Gregersen's claim is not well founded. The series of articles represents overviews of the historical background to current science-religion debates with regard to content, amongst others, in Latin America (Silva 2015), Germany (Evers 2015), Catholic Southern Europe (Oviedo \& Garre 2015), South Africa (Du Toit \& Conradie 2015), China (Li \& Fu 2015), Japan (Kim 2015) and the United Kingdom (Southgate 2016). It also gives a broad overview of the debates within Islam and Science (see Guessoum 2015). Given the very interesting diverse overviews that come from the different contexts, Drees (2015) therefore - in this long quotation - rightfully states and demands:

'Glocalization' is a neologism to speak of the complex interplay of global and local. If one looks it up in Wikipedia, it is mostly about marketing, adapting global brands and products to local preferences in order to be more successful commercially. That is still too close to an export model, in my opinion. The process runs deeper than that; the local dimension, the emphasis on particularity, is not merely instrumental but ought to be considered to be a genuine source of insight. We should give people from various settings an opportunity to speak for themselves, and to present on their own terms, how knowledge and values interact in their cultural and social context. (p. 153)

To substantiate the above, a few examples must suffice. For his context, Evers (2015) remarks:

In Germany, the interaction between science, religious views, ultimate concerns, unconditional values, and theological reflection will presumably continue to be only a sideline of academic discourse ... German academic theology is mainly related to cultural studies, and is less interested in, and hardly competent in relating to, different fields of science. (p. 529)

For the Latin American context, Silva (2015:480) writes, 'The state of the debate surrounding issues on science and religion in Latin America is mostly unknown, both to regional and extra-regional scholars'. In his conclusion, Silva (2015:499) finds that 'Latin American scholars are still somewhat isolated from the international discussion on science and religion, while being at the same time isolated from each other'. The South African scholars Du Toit and Conradie (2015) remarks:

Until now, the focus on science and the science-religion interface was perhaps seen as an unaffordable luxury for the poor. Economic growth, increasing urbanization, and continued investment in science education will inevitably bring religious questions to the fore. Against this background, the pioneering work in the science-religion interface may serve as a matrix for further development. (p. 476)

Perhaps, the most fascinating remarks come from the Japanese scholar Kim (2015) who concludes:

What then might the science-religion dialogue in Japan contribute to the science-religion dialogue in the West? Could we expect from the Japanese approach to the science-religion dialogue a new paradigm for understanding and describing ultimate reality? Or, might the Japanese approach disclose a point of view where there is neither 'religion' nor 'science' at all? Such questions urge us to observe carefully what is going on in the science-religion dialogue in Japan, a country in East Asia where conventional conceptions of 'religion', 'science', and even of ‘God' are foreign and unfamiliar. (p. 170)

The aforegoing remark by Drees that:

we should give people from various settings an opportunity to speak for themselves, and to present on their own terms, how knowledge and values interact in their cultural and social context

is, in my opinion, the direction in which we should be going, making work of the 'glocal' overviews! Not as polite invite as if I am in some or other 'normative position' to invite the 'others', but precisely as constitutive of the metaphysical 'event' (see more on the 'event' below). If, as Van Huyssteen and Gregersen (1998:3ff.) state, a Second Generation as distinguished from the First Generation ${ }^{16}$ of scholars of the science-religion dialogue has focused more strongly on cognitive pluralism within the West, then I would like to argue that a Third Generation has already merged. A Third Generation that are building on the previous generations and are now taking evolutionary processes (the nature and implications thereof) even more seriously in a deeper holistic and interdisciplinary manner (cf., for example, the earlier reference to niche construction). The latter not only has vast

16.The three scientist-theologians most associated with the development of the science-religion dialogue as 'First Generation' between 1970 and the early 2000s

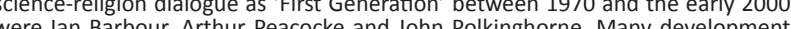
were lan Barbour, Arthur Peacocke and John Polkinghorne. Many developments since then have me with radical revisins. Or very influential depiction of the nature of the science-religion dialogue. Fitting all in the scheme of four categories as Barbour suggested, namely conflict, independence, dialogue and integration, simply does not hold any longer. 
implications especially for our unfolding of the 'place of metaphysics' but also to understand the current extremely diverse and messy dialogues that have not managed to 'successfully transform itself'.

\section{Conclusion}

I have barely scraped the surface in trying to find a 'place' for metaphysics in science and theology, and I have come to the uncomfortable conclusion that it is really nowhere to be found. It has no place if understood as preferential option for 'universal content', for an a priori viewpoint. Let me try to explain in the light of my exposition of the negative and positive thrust and the direction of developments of the conversation partners (science; religion/theology) and the dialogical relationship.

Metaphysics is nowhere to be found in science and religion as 'is'. However, it can be 'found' as 'was'. I would try to explain, in an analogical sense, the difference between the 'is' and 'was' from physics, namely from the movement of atoms.

It is nowhere to be found almost like the 'non-foundability' (non-localisation) of atoms of which we can only theoretically say afterwards where they have been (but not that they are here now). That, however, does not imply in any way that they do not exist as physical entities. We can see them 'afterwards' with our theories (and then work forward with those very theories). In that sense, they are very much metaphysical, that is, being 'coming and located afterwards'. What I thus think I did find is that metaphysics does not occupy place as such, but represent a dimension of an afterwards event ('it takes place'). It is an 'ingredient' of the sense-making life of 'beholders' of 'being'/'beingness' as they journey linguistic-culturally 'within' contexts. Contexts of which they make sense in all kinds of ways from the 'givenness' ${ }^{\prime 17}$ they experience and question from that very implicit/explicit - specific located sense-making frames (ranging from Platonism to Aristotelianism to Thomism to Idealism to Dualism).

What I do find directional for my further journey on 'metaphysics' from the aforegoing is the conviction that the sense-making activities of the beholders from their linguisticcultural contexts are determined - the structure and nature thereof - by the biological evolutionary processes which formed them. In other words, our understanding of metaphysics must be approached from the very evolutionary processes that made such thinking in the first place a dimension of being human. This is the best insight to work from in making sense of the varieties and immense differences that we find in the science-religion dialogues around the

17.For my understanding of the word 'givenness', i have the French philosopher JeanLuc Marion's phenomenological proposal in the back of my head. Marion focuses on the possibility and logic of the gift. For him, givenness cannot be reduced to the dichotomy of the object (realism) and the mere appearing of things (phenomenology). Givenness, manifested by a process of strict immanence, is neither object, nor is it appearance, nor is it even being, but something beyond all of these. It is where causality has been radically surpassed. Saturated givenness surpasses the concept of being. He identifies four modes of givenness, namely the event, the idol, the flesh and the icon (Marion 2002:234-245). See Compaan event, the idol, the flesh and the icon (Marion 2002:234-245). See Compaan
(2015) for a very recent and in-depth discussion of Marion's so-called postmetaphysical viewpoint. world. That implies that the 'was' of metaphysical thinking represents the emergent product - as inferred consequence (see introductory quotation) - of the concrete and specific lifeworlds in which they have 'taken place', that is, 'eventuated'. ${ }^{18}$ Insightfully, Fuentes (2015:6) calls this 'our cognitive ecology'.

The 'cognitive ecology' (Fuentes) of metaphysical reflection helps us - in my opinion - to understand that within the science-religion dialogues, metaphysics has no place and is nowhere to be found as 'is', but only as an (after) 'was'. It turns place into event, and in this way, metaphysical reflection becomes the 'afterwards story' on being human and personhood that has accepted the 'seen' (the natural sciences) and 'heard' (religious reflection) invitation from the realities it experiences into inferred sense-making frameworks. The 'was' of metaphysical reflection is surely the most powerful (a posteriori) event of credofication for human beings in living, spelling and participating empathically in the question 'why there is something rather than nothing?'.

\section{Acknowledgements Competing interests}

The author declares that he has no financial or personal relationships which may have inappropriately influenced him in writing this article.

\section{References}

Badiou, A., 2006, Briefings on existence: A short treatise on transitory ontology, SUNY Press, Albany, NY.

Brooke, J.H., 2006, 'The history of science and religion', in P. Clayton (ed.), The Oxford handbook of science and religion, Oxford University Press, Oxford.

Clayton, P., 2005, 'Theology and the physical sciences', in D. Ford (ed.), Modern theologians, pp. 342-356, Blackwell, Oxford.

Compaan, A., 2015, 'The revelation of Christ as an impossible impossibility: A critical reading of Jean-Luc Marion's contribution to the post-modern debate in phenomenology, philosophy of religion and theology', Stellenbosch Theological Journal 1(1), 57-77. http://doi.org/10.17570/stj.2015.v1n1.a3

Conradie, E.M. \& du Toit, C.W., 2015, 'Knowledge, values and beliefs in the South African context since 1948: An overview', Zygon 50(2), 455-479. https://doi. org/10.1111/zygo.12167

Drees, W.B., 2015a, 'The future of religion and science around the world', Zygon 50(2), 267-270. http://doi.org/10.1111/zygo.12182

Drees, W.B., 2015b, 'Glocalisation: Religion and science around the world', Zygon 50(1), 151-154. https://doi.org/10.1111/zygo.12155

Du Toit, C., 2013, 'A scientific defence of religion and the religious accommodation of science? Contextual challenges and paradoxes', HTS Theological Studies 69(1), 1-9. http://doi.org/10.4102/hts.v69i1.1293

Ellis, G., 2006, 'Physics, complexity, and religion', in P. Clayton (ed.), The Oxford handbook of science and religion, pp. 751-767, Oxford University Press, Oxford.

18.In this sense, go with and support the more sophisticated formulation of Fuentes in his approach which he calls 'niche construction'. What I have said here in brief is in his approach which he calls niche construction". What I have said here in brief is that Fuentes (2015:3) formulates much better and more clearly on niche
construction: The human niche is the spatial and social sphere that includes the social partners, perceptual contexts, and ecologies for human individuals and communities and the many other species sympatric with humans. The human niche is the context for the lived experience of humans today as it was for earlier humans and their communities, where they shared kinship (biological and social) and social and ecological histories, and where they created and participated in shared knowledge, social and structural security, and development across the lifespan. And elsewhere with specific reference to the topic under discussion: A key to understanding human consciousness and our capacity for metaphysical and eventually religious thought is to recognise that while our symbolic mode of existence is emergent: our way of being arises from the interactions of many elements (bodies, brains,

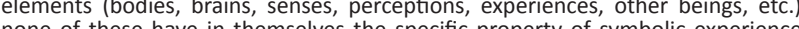
ne the components of the human niche... Humans, both as individuals and as communities, are embedded in a niche wherein navigation and creation of symbolic landscapes is a permanent context of our cognitive ecology (Fuentes 2015:6). 
Evers, D., 2015, 'Religion and science in Germany', Zygon 50(2), 503-533. https://doi. org/10.1111/zygo.12172

Fuentes, A., 2015, 'Niche construction and religious evolution', in Oxford research encyclopaedia of religion, Oxford University Press, Oxford, e-30.

Gill, M.L., 2005, 'Aristotle's metaphysics reconsidered', Journal of the History of Philosophy 43(3), 223-241. https://doi.org/10.1353/hph.2005.0138

Gillett, C., 2006, 'The hidden battles over emergence', in P. Clayton (ed.), Oxford handbook of science and religion, pp. 801-821, Oxford University Press, Oxford.

Gregersen, N., 2006, Emergence: What is at stake for religious reflection? in P. Clayton (ed.), Oxford Handbook of science and religion, pp. 767-784, Oxford University Press, Oxford.

Gregersen, N. \& Van Huyssteen, W. (eds.), 1998, Rethinking theology and science, Eerdmans, Grand Rapids, MI.

Guessoum, N., 2015, 'Islam and science: The next phase of the debate', Zygon 50(4), 854-876. https://doi.org/10.1111/zygo.12213

Heidegger, M., 2001, Sein und Zeit, Schoenhofsforeign Books, Cambridge.

Kaufman, G., 1978, 'Metaphysics and theology', Cross Currents 28, 325-341.

Kim, S.C.K., 2015, 'SŪNYATĀ and KOKORO: Science-religion dialogue in the Japanese context', Zygon 50(1), 155-171. https://doi.org/10.1111/zygo.12153

Li, J. \& Fu, Z., 2015, 'The craziness for extra-sensory perception: Qigong fever and the science-pseudoscience debate in China', Zygon 50(2), 534-547. https://doi. org/10.1111/zygo.12178

Marion, J.L., 2002, Being given: Toward a phenomenology of givenness, Stanford University Press, Stanford, CA.

Maudlin, T., 2003, 'Distilling metaphysics from quantum mechanics', in M.J. Loux \& D.W. Zimmermann (eds.), The Oxford handbook of metaphysics, pp. 461-490, Oxford University, New York.

McGrath, A.E., 2004, The science of God, Eerdmans, Grand Rapids, MI.
McGrath, A.E., 2011, Surprised by meaning: Science, faith, and how we make sense of things, Westminster John Knox, Louisville, KY.

Ormerod, N., 2013, 'Theology and the new atheism: Science, religion and metaphysics', Theology 116(3), 187-194. https://doi.org/10.1177/0040571X12472598

Oviedo, L. \& Garre, A., 2015, 'The interaction between religion and science in Catholic Southern Europe (Italy, Spain, Portugal)', Zygon 50(1), 1. https://doi.org/10.1111/ zygo.12159

Scott, C., 2015, 'Primary causality: In defense of the metaphysical rationality of faith in God as creator', Verbum et Ecclesia 36(1), Art: 1377, 1-8.

Scott, C., 2016, 'The frontiers of empirical science: A Thomist-inspired critique of scientism', HTS Theological Studies 72(3) a3180, 1-10.

Silva, I., 2015, 'Science and religion in Latin America: Developments and prospects', Zygon 50(2), 480-502. https://doi.org/10.1111/zygo.12176

Southgate, C., 2016, 'Science and religion in the United Kingdom: A personal view on the contemporary scene', Zygon 51(2), 361-386. https://doi.org/10.1111/ zygo.12248

Taylor, C., 2007, A secular age, Belknap The Belknap Press of Harvard University Press, Cambridge.

Van der Meer, J., 2003, 'Metaphysics', in Van Huyssteen, J Wentzel Vrede (ed.) Encyclopedia of science and religion, pp. 561-563, MacMillan, Detroit.

Van Huyssteen, W., 1986, Teologie as kritiese geloofsverantwoording, RGN, Pretoria.

Veldsman, D., 2014, 'With reasons of the heart before God. On religious experience from an evolutionary perspective', NGTT 55(1-2), 1-18. http://doi.org/10.5952/ 55-1-2-534

Wikipedia, 2017a, Margaret Wolfe Hungerford, viewed 21 February 2017, from https://en.wikipedia.org/wiki/Margaret_Wolfe_Hungerford

Wikipedia, 2017b, Radical orthodoxy, viewed 21 February 2017, from https://en. wikipedia.org/wiki/Radical_Orthodoxy 